\title{
Modelling and Forecasting Electricity Demand for Commercial and Industrial Consumers in Kenya to 2035
}

\author{
Grace Njeru, MA \\ John Gathiaka, PhD \\ Prof. Peter Kimuyu, PhD \\ School of Economics, University of Nairobi
}

Doi:10.19044/esj.2020.v16n13p162 URL:http://dx.doi.org/10.19044/esj.2020.v16n13p162

\begin{abstract}
Commercial and industrial consumers are the largest users of electrical energy in Kenya. They play a central role in driving electricity demand by contributing to over $70 \%$ of the electricity demand in the country. Despite their consumption of electricity being the highest, there is a gap on the drivers of their demand. There are significant deviations between past official forecasts and actual putting into question the official forecast assumptions. This study adressed this gap by estimating the drivers of commercial and industrial electricity demand.The drivers included supply side constraints represented by hydro inflows hence contributing to literature. A demand forecast upto to the year 2035 was also undertaken and compared with the official forecast. Autoregressive distributed lag (ARDL) method and time series data from 1985 to 2016 was used in undertaking the analysis. The results indicated that commercial and industrial consumers' electricity demand is income elastic. Other drivers include efficiency, electricity price and hydro inflows. A projection of the demand indicated the official forecast could be overstated and may need to be reviewed.
\end{abstract}

Keywords: Commercial and industrial electricity consumers, Electricity demand, ARDL, Kenya

\section{Introduction}

The Kenya Vision 2030 identified six priority sectors that would drive the GDP growth to $10 \%$. The sectors identified were tourism, agriculture, livestock, wholesale, retail, trade, manufacturing, finance and business process outsourcing. The sectors were selected due to their contribution to the economy making up to 57\% of the GDP and employing about half of the population (Republic of Kenya, 2007). These sectors are classified as 
commercial and industrial consumers of electricity (Electricity Regulatory Board, 2005). They are also the highest consumers of electrical energy at $70 \%$ of total energy consumed in the country. Despite the number of customers accounting for less than $10 \%$ of the total connections (Lahmeyer, International $\mathrm{GmbH}, 2016$ ). Therefore, for the Government to succeed in achieving the goals of the Vision 2030 there needs to have reliable and affordable supply of electricity to these sectors.

In a regulated market without a wholesale market such as Kenya, the purchase and supply of electricity is centralised. Kenya Power and Lighting Company (KPLC) undertakes the monopsonist role in the electricity sector. The reforms of 1998 unbundled KPLC from a vertically integrated utility, created an independent regulatory authority and allowed for private sector participation in power generation. All generators sign long term power purchase agreements with KPLC.The demand forecast defines the generation capacity to be added to the electricity interconnected system. It is undertaken prior to generation planning. This makes demand forecasting a critical step in the procurement of generation capacity and in retail tariffs designs (Electricity Regulatory Board, 2005).

An over projection of electricity demand could lead to overinvestment and high costs of electricity. This is because in determining electricity prices, the regulator relies on the total future costs of supply as well as demand to come up with cost-reflective tariffs. The cost of supply includes the expenses from generation, transmission, distribution, metering and billing (Electricity Regulatory Board, 2005). The projected demand affects electricity prices in two ways. First, the price per unit is based on the projected energy sales. The higher the sales compared to the total costs of supply the lower would be the price and conversely. Second, all investment requirements are dependent on future electricity demand (Electricity Regulatory Board, 2005). Therefore, the demand forecast for commericial and industrial consumers being the largest consumers of energy plays a critical role in determining the investment and costs of electricity.

Currently, electricity demand forecast for commercial and industrial consumers is undertaken using an end user model. The model multiplies the base electricity consumption with the GDP growth forecast and a correlation factor. The correlation factor is estimated using past GDP and electricity consumption data. The coefficient used in forecasting has ranged from 1- 1.5 (Republic of Kenya, 2013b; Lahmeyer International GmbH, 2016). The forecasting method therefore assumes the only driver of commercial and industrial electricity demand is GDP. The role of prices in the demand is not considered, a weakness of the end user models (Bhattacharyya, 2011). There is therefore need to explore the drivers of commercial and industrial energy demand using an econometric approach. The approach treats electricity 
demand like demand for a normal good or service, by exploring the price, quantity and other drivers' relationship.

The GDP growth rate in the last five years averaged $5.64 \%$ (Kenya National Bureau of Statistics (KNBS), 2019) while electricity consumption by commercial and industrial consumers averaged 3\% (KPLC, 2019). This indicates the need to reassess the correlation factor used in forecasting demand. Table 1 presents the deviations between previous official forecasts and actual. The deviations put into question the official forecast assumptions.

This article attempted to fill this research gap by forecasting and estimating the drivers of commercial and industrial electricity demand using autoregressive distributed lag (ARDL) econometric methods. The article also contributed to literature by examining the effects of supply side constraints on the demand. Supply side constraints existing in a developing country such as Kenya include system outages and load shedding during drought period due to overdependence on hydro generated energy. The article sought to answer the following research questions: What drives commercial and industrial consumer's electricity demand? What are the price and income elasticities? How does the demand forecast based on econometric estimations compare with the official forecast?

Table 1: Comparison of previous official projections and actual demand

\begin{tabular}{|c|c|c|c|c|c|}
\hline & \multicolumn{2}{|c|}{ Energy consumption in GWh } & \multicolumn{2}{c|}{ Deviation from Actual } \\
\hline Year & $\begin{array}{c}\text { Kepublic of } \\
\text { Kenya (2013b) } \\
\text { Forecast }\end{array}$ & $\begin{array}{c}\text { Lahmeyer } \\
\text { International } \\
\text { GmbH (2016) } \\
\text { Forecast }\end{array}$ & $\begin{array}{c}\text { Actual Sales } \\
\text { (KPLC, 2019) }\end{array}$ & $\begin{array}{c}\text { Republic of } \\
\text { Kenya (2013b) } \\
\text { Forecast }\end{array}$ & $\begin{array}{c}\text { International } \\
\text { GmbH (2016) } \\
\text { Forecast }\end{array}$ \\
\hline 2016 & 7583 & 5783 & 5416 & $41.4 \%$ & $7.9 \%$ \\
\hline 2017 & 8804 & 6136 & 5664 & $61.3 \%$ & $12.4 \%$ \\
\hline 2018 & 10125 & 6501 & 5611 & $81.5 \%$ & $16.5 \%$ \\
\hline
\end{tabular}

Source: Author's compilation from Lahmeyer International GmbH (2016), Republic of Kenya (2013b) and KPLC (2019)

\section{Literature review}

The theoritical foundation of energy demand is similar to that of other normal goods and should therefore be presented through a demand function. The theory of production is used to determine the demand for energy as a factor of production (Bhattacharyya, 2011). Commercial and industrial consumers use electricity as an input in production and are faced with a cost minimization objective. The factor demand functions are derived from the firms cost minimization objective, where output is produced at the point the technical rate of substitution equals the ratio of the inputs prices (Bhattacharyya and Timilsina, 2009).Thus, demand for electricity in firms is a derived demand. 
Khayyat (2015) derives the demand function for energy from a production function using the Shephard's lemma approach. The resultant demand function specificies energy to be dependent on output, own price and price of alternative energy. The price of alternative energy captures substitution and complimentarity effects. The dependency of energy demand on output and price is supported by Bhattacharyya (2011) and Bhattacharyya and Timilsina (2009). A long-run relationship between GDP and energy demand has also been established by Magazzino (2014).

The empricial literature on commercial and industrial electricity demand is quite limited. The earliest work in this area is by Francisco (1988) in Philippines. The work identifies electricity price, income and price of alternatives to be the significant determinants of demand. Several recent studies consider price and income/output as the only drivers of commercial and industrial electricity consumption. These include Campbell (2018) in Jamaica, Bianco, Manca, Nardini and Minea (2010) in Romania, Bernstein and Madlener (2010) in Germany, Chaudhry (2010) in Pakistan, and Bjørner and Togeby (1999) in Denmark.

Studies have identified other determinants of demand. Cebula and Herder (2010) finds the consumption of electricity demand by commercial and industrial consumers in the United States increasing with cooling degree days, per capita disposable income and electricity generating capacity. Consumption decreases with price of electricity and energy efficiency. Otsuka (2015) study for Japan also finds commercial and industrial electricity demand to increase with temperature factors and output and, decrease with price.

Dilaver and Hunt (2010) show that industrial electricity demand in Turkey is driven by industrial value addition, electricity price and the underlying trend. Ghaderi, Azadeh and Mohammadzadeh (2006b) find the demand drivers of various industrial sectors in Iran to include electricity prices, number of industrial customers and industrial value addition. Their earlier study (2006a) has price of substitutes and electricity intensity as additional drivers of demand. A study for Pakistan by Sabir, Ahmad and Bashir (2013) also finds price of oil as a substitute to be a significant driver of industrial electricity demand. Other significant drivers include own price and industrial share of GDP.

Past estimates of elasticities of demand for commercial and industrial electricity are varied. Cebule and Herder (2010) find income elasticity of 1.57 and price elasticity of -0.887 in the United States. A recent study for industrial consumers in the United States finds price elasticity of -1.17 and income elasticity of 0.48 (Burke and Abayasekara, 2018). Bjornerand and Togeby (1999) have income and price elasticity for Denmark at 0.611 and -0.473 , respectively. In Turkey, Dilaver and Hunt (2010) find income and price elasticity of 0.15 and -0.161 , respectively. In Jamaica, Campbell (2018) finds 
income and price elasticities of 1.22 and -0.25 for industrial consumers respectively.

In Pakistan, Chaudhry (2010) finds the income and price elasticity of commercial and industrial demand is 0.194, and -0.574, respectively. Comparable estimates in Iran are 0.11 and -0.21 , respectively (Ghaderi et al., 2006b). Separating high from low energy consuming industries in Iran, Ghaderi et al. (2006a) finds high energy consuming industries to be price elastic with an elasticity of -2.92 . Low energy consuming industries have a price elasticity of -0.93. Sabir et al. (2013) study for Pakistan estimates the income elasticity to be 0.96 and price elasticity to be -0.28 .

Some studies have seperate estimates for the short and long-run elasticities. Bianco et al. (2010) in Romania finds short-run income and price elasticity of 0.136 and -0.0752 , respectively. The long-run elasticities are slightly higher at 0.496 and -0.274 , respectively. Otsuka (2015) study for Japan also finds higher income elasticities in the long-run compared to the short-run. In the long-run, the income elasticity is 1.169 for the industrial sector and 1.106 for the commercial sector.The short-run income elasticity for industrial consumers is 0.274 while that of commercial consumers is 0.358 .

From the studies reviewed, the main determinants of demand for electricity are output/income and electricity price. Other determinants are price of alternatives, energy efficiency, temperature (cooling degree days), number of customers and energy intensity. Temperature may, however, not be a relevant determinant in the Kenyan case. The climate is warm all year round with minimal variations in temperatures. The reviews of elasticity of demand for electricity showed varied results across consumer groups and countries. Long-run elasticities were found to be higher than the short-run elasticities. This could be attributable to the period required for consumers to adjust to price and income changes.

Demand forecasting is undertaken using the relationship established in the demand function. Forecasting is undertaken by changing the values in the independent variables for the forecast period and determining their effect on the dependent variable. Forecasting of the independent variables is based on judgement, trends and projected national growth rates (Bhattacharyya, 2011; Dilaver and Hunt, 2010; Ghaderi et al., 2006a). Studies consider various scenarios. In Iran Ghaderi et al. (2006a) considered three scenarios that is low, high and average. Dilaver and Hunt (2010) study for Turkey also considers the three scenario with average being the reference and most probable scenario. 


\section{Methodology}

Following Cebule and Herder (2010) the commercial and industrial electricity demand function was specified as

$$
C I E=f\left(Y, P_{e}, P_{d}, E F_{i c}, H, C_{i c}, D_{1}\right)
$$

where $C I E$ was the electricity consumed by the commercial and industrial consumers, $Y$ was income/output, $P_{e}$ was electricity price, $P_{d}$ was price of the alternative fuel (Diesel), $E F_{i c}$ was efficiency levels in production, $H$ was hydro inflows as a proxy for supply side constraints and $C_{i c}$ was the number of commercial and industrial consumers. $D_{1}$ was a dummy variable to correct for structural breaks associated with reforms of 1998.

Equation 1 was rewritten as follows;

$$
C I E_{t}=e^{\alpha} P_{e t}^{a} P_{d t}^{b} E F_{i c t}^{c} H_{t}^{d} C_{i c t}^{e}, Y_{t}^{f} e^{g D_{1}} e^{\varepsilon_{t}}
$$

where $\alpha, a, b, c, d, e$, fand $g$ were coefficients to be estimated, $\varepsilon$ was the error term and $t$ was time period.

The log linear form of equation (2) becomes

$$
\begin{aligned}
& \ln C I E_{t}=\alpha+a \ln P_{e t}+b \ln P_{d t}+c \ln E F_{i c t}+d \ln H_{t}+e \ln C_{i c t}+ \\
& f \ln Y_{t}+g D_{1}+\varepsilon_{t}
\end{aligned}
$$

Equation (3) error correction model took the following form;

$$
\begin{array}{r}
\Delta \ln C I E_{t}=\alpha+\sum_{i=1}^{n} \beta_{i} \Delta \ln C I E_{t-i}+\sum_{i=0}^{n} a_{i} \Delta \ln P_{e t-i}+\sum_{i=0}^{n} b_{i} \Delta \ln P_{d t-i}+ \\
\sum_{i=0}^{n} c_{i} \Delta \ln E F_{i c t-i}+\sum_{i=0}^{n} d_{i} \Delta \ln H_{t-i}+\sum_{i=0}^{n} e_{i} \Delta \ln C_{i c t-i}+ \\
\sum_{i=0}^{n} f_{i} \Delta \ln Y_{t-i}+\emptyset_{1} \ln C I E_{t-1}+\emptyset_{2} \ln P_{e t-1}+\emptyset_{3} \ln P_{d t-1}+ \\
\emptyset_{4} \ln E F_{i c t-1}+\emptyset_{5} \ln H_{t-1}+\emptyset_{6} \ln C_{i c t-1}+\emptyset_{7} \ln Y_{t-1}+g D_{1}+\varepsilon_{t}
\end{array}
$$

where $\beta_{i}, a_{i}, b_{i}, c_{i}, d_{i}, e_{i}, f_{i}$ and $g$ were short-run coefficients and $\emptyset_{1} \ldots \emptyset_{7}$ were long-run coefficients. Equation 4 was estimated using the Autoregressive Distributed lag model (ARDL). Bounds testing cointegration approach was used to test for the existence of a long-run relationship. The test has the advantage of working with small samples (Belloumi, 2014) and stationary and nonstationary data (Pesaran, Shin and Smith, 2001).

The long-run ARDL model was used for forecasting the future demand. This was done by changing the independent variables and determining their effect on CIE (Bhattacharyya, 2011). The independent future variables were amended based on predictions in goverement documents and judgement. 


\subsection{Data and measurement}

The annual data used in the analysis was for the period 1985-2016 ( 32 years) sourced from KPLC annual reports, Kenya National Bureau of Statistics Economic Surveys and Statistical Abstracts, World Bank, World Development Indicators and KenGen.

Table 2: Definition and measurement of variables used to estimate commercial and industrial demand for electricity in Kenya.

\begin{tabular}{|c|c|c|}
\hline Variable & Definition and measurement & Source \\
\hline$C I E$ & $\begin{array}{l}\text { Annual electricity sales to } \\
\text { commercial and industrial } \\
\text { consumers }(\mathrm{GWh})\end{array}$ & KPLC annual reports, various \\
\hline$P_{e}$ & $\begin{array}{l}\text { Real price of electricity } \\
\text { (Ksh/200kWh) based period } \\
\text { February } 2009 .\end{array}$ & $\begin{array}{l}\text { KNBS statistical abstracts, } \\
\text { various }\end{array}$ \\
\hline$P_{d}$ & $\begin{array}{l}\text { Annual diesel Price per litre (Ksh/) } \\
\text { base period February } 2009 .\end{array}$ & $\begin{array}{l}\text { KNBS statistical abstracts, } \\
\text { various }\end{array}$ \\
\hline$E F_{i c}$ & $\begin{array}{l}\text { Computed by dividing the annual } \\
\text { value added produced by industry } \\
\text { with the annual electricity sales to } \\
\text { commercial and industry consumers } \\
\text { (Ksh/kWh). }\end{array}$ & $\begin{array}{l}\text { The value added produced from } \\
\text { Industry was collected from } \\
\text { world bank statistics, World } \\
\text { Development Indicators. } \\
\text { Electrical energy consumed by } \\
\text { industry was collected from } \\
\text { KPLC annual reports }\end{array}$ \\
\hline$H$ & $\begin{array}{l}\text { Total annual hydro inflows } \\
\text { (Cumecs). }\end{array}$ & KENGEN \\
\hline$Y$ & $\begin{array}{l}\text { Annual constant gross value added } \\
\text { in Ksh }\end{array}$ & $\begin{array}{l}\text { World Bank statistics, World } \\
\text { Development Indicators }\end{array}$ \\
\hline$C_{i c}$ & $\begin{array}{l}\text { Number of commercial and } \\
\text { industrial customers as reported in } \\
\text { KPLC annual reports }\end{array}$ & KPLC annual reports, various \\
\hline$D_{1}$ & $\begin{array}{l}\text { Dummy variable. Captures the first } \\
\text { Electricity sector reforms. } 1985- \\
1997=0 \text { and } 1998-2015=1\end{array}$ & \\
\hline
\end{tabular}

\section{Results and discussion}

Eviews 10 software was used for the analysis. The number of customers and diesel were dropped from the estimation to reduce collinearity in the model. 
Table 3: Summary statistics of variables used in the analysis.

\begin{tabular}{|l|l|l|l|l|l|l|}
\hline Variable & Unit & Mean & $\begin{array}{l}\text { Std. } \\
\text { deviation }\end{array}$ & Min & Median & Max \\
\hline $\begin{array}{l}\text { Commercial and industrial } \\
\text { electricity consumption }\end{array}$ & GWh & 2941 & 1148 & 1476 & 2557 & 5362 \\
\hline Number of customers & No. & 136122 & 83679 & 38695 & 109157 & 324801 \\
\hline Diesel price & Kshs/Liter & 66 & 47 & 9 & 58 & 148 \\
\hline Energy Efficiency & Kshs/kWh & 158 & 14 & 139 & 156 & 187 \\
\hline Output & Kshs Trillion & 2.12 & 0.72 & 1.18 & 2.766 & 3.81 \\
\hline Hydro inflows & Cumecs & 862 & 262 & 466 & 833 & 1559 \\
\hline Price of Electricity & Kshs/200kWh & 56 & 44 & 7 & 45 & 138 \\
\hline
\end{tabular}

Source: Author's computation from KPLC, KNBS, World Bank and KenGen data.

Table 3 provides the summary statistics of the data before the logarithmic transformation. Commercial and industrial consumption averaged 2,941GWh increasing from 1,476GWh in 1985 to 5,362GWh in 2016. The number of customers' averaged 136,122 while energy efficiency averaged Ksh $158 / \mathrm{kWh}$. The highest efficiency level of kshs187/kWh was realised in 2001 a period that was marked with power rationing. The gross value added representing income/output averaged Ksh 2,117 billion having increased from Kshs 1,178 billion in 1985 to Kshs 3,809 billion in 2016. Hydro inflows averaged 862 cubic metre per second with the least inflows of 466 cubic metre being for the drought period of 2008. Electricity price averaged Kshs 56/200 kWh, the highest price of Kshs 138/200kWh was recorded in 2014 and could be associated with the electricity tariff review of December 2013. Diesel prices averaged Kshs 66 per liter.

\subsection{Diagnostic tests Unit root tests}

Table 4:Unit root test

\begin{tabular}{|c|c|c|c|c|c|c|}
\hline Variable & ADF & $\mathbf{P P}$ & DF-GLS & KPSS & Breakpoint & Conclusion \\
\hline \begin{tabular}{|l}
$\mathrm{Y}_{\mathrm{t}^{-}}$ \\
Intercept
\end{tabular} & 1.6861 & 1.4834 & 1.1003 & 0.7507 & -0.9919 & \multirow{2}{*}{$\begin{array}{l}\text { we reject the } \\
\text { null hypothesis } \\
\text { of a unit root, } \\
\text { the series are } \\
\text { stationary based } \\
\text { on the KPSS } \\
\text { test. }\end{array}$} \\
\hline $\begin{array}{l}\text { Intercept } \\
\text { and Trend }\end{array}$ & 0.2130 & -0.0620 & -0.3929 & 0.1708 & -4.1202 & \\
\hline \begin{tabular}{|l}
$\mathrm{H}_{\mathrm{t}}$ \\
Intercept
\end{tabular} & -4.7899 & -3.9734 & -4.8675 & 0.3166 & -6.2109 & \multirow{2}{*}{$\begin{array}{l}\text { we reject the } \\
\text { null hypothesis } \\
\text { of a unit root, } \\
\text { the series are } \\
\text { stationary based } \\
\text { on all the tests. }\end{array}$} \\
\hline $\begin{array}{l}\text { Intercept } \\
\text { and Trend }\end{array}$ & $\mid-5.3143$ & -6.2777 & -5.4709 & 0.2862 & -6.0981 & \\
\hline $\begin{array}{l}\mathrm{P}_{\mathrm{t}^{-}} \\
\text {Intercept }\end{array}$ & -1.2549 & -1.2549 & -0.2166 & 0.7149 & -2.6779 & $\begin{array}{l}\text { we reject the } \\
\text { null hypothesis }\end{array}$ \\
\hline
\end{tabular}




\begin{tabular}{|l|l|l|l|l|l|l|}
\hline Variable & ADF & PP & DF-GLS & KPSS & Breakpoint & $\begin{array}{l}\text { Conclusion } \\
\text { of a unit root, } \\
\text { the series are } \\
\text { and Trend } \\
\text { stationary based } \\
\text { on the DF-GLS } \\
\text { and PP tests. }\end{array}$ \\
\hline $\begin{array}{l}\text { CIE } \\
\text { Intercept }\end{array}$ & -2.3869 & -2.3953 & -2.4938 & 0.1406 & -6.7625 & \\
\hline $\begin{array}{l}\text { Intercept } \\
\text { and Trend } \\
\text { null hypothesis } \\
\text { of a unit root, } \\
\text { the series are } \\
\text { stationary based } \\
\text { on the } \\
\text { breakpoint unit } \\
\text { roor test. }\end{array}$ \\
\hline $\begin{array}{l}\text { EF } \\
\text { Intercept }\end{array}$
\end{tabular}

Source: Author estimates from KPLC, Economic surveys, World Bank statistics and KenGen data.

Critical levels at $1 \%, 5 \%$, and $10 \%$ significance levels are as follows; Intercept ADF( -3.662,2.960,-2.619), PP (-3.661661,-2.960411,-2.619160), KPSS (0.739000, 0.463000, 0.347000), DF-GLS (-2.644302,-1.952473,-1.610211) Break point (-4.949133, -4.443649, -4.193627) Intercept and Trend ADF(-4.309824, -3.574244, -3.221728) PP (-4.296729, -3.568379, 3.218382), KPSS $(0.216000,0.146000,0.119000)$, DF-GLS (-3.77, -3.19,-2.89), break point; (-5.347598, -4.859812, -4.607324 - Intercept; -5.719131, -5.17571, -4.89395 - Trend and intercept; $-5.067425,-4.524826,-4.261048)$

The unit roots test details are in Table 4. Any variable found to be stationary at level by either the ADF, PP, DF-GLS, KPSS and break point unit root tests was considered I (0). All the variables were therefore I (0). This means the estimation using the ARDL bounds testing procedure which requires the variables to be either I (0) or I(1) (Pesaran et al, 2001), could proceed. Structural breaks with respect to the energy efficiency, hydro inflows and sales occurred in 1998. This was corrected by including the dummy variable called reform. Stationarity of the variables also makes it possible for the use of the series past behavior to forecast future movements (Magazzino, 2017).

\section{Lag length, Residual and Stability tests}

The Lag length 3 model failed the residual and stability diagnostic tests. Lag length 2 no intercept no trend model failed the Heteroskedasticity residual diagnostic test while the intercept with trend model failed the 
CUSUM stability test. The model that passed all the test was $\operatorname{ARDL}(2,2,0$, $1,2)$ with a constant and no trend. Table 5 presents the lag length selection results. Table 6 provides the residual and stability diagnostic test results of the selected model. The CUSUM and CUSUM of squares results are presented in figure 1.This model was tested for cointegration and to analyse the commercial and industrial electricity demand.

Table 5: Lag length selection results

\begin{tabular}{|l|l|l|l|l|}
\hline & $\begin{array}{l}\text { Akaike } \\
\text { information } \\
\text { criterion }\end{array}$ & $\begin{array}{l}\text { Bayesian } \\
\text { information } \\
\text { criterion }\end{array}$ & $\begin{array}{l}\text { Hannan-Quinn } \\
\text { criterion }\end{array}$ & $\begin{array}{l}\text { Adjusted } \\
\text { R-squared. }\end{array}$ \\
\hline $\operatorname{ARDL}(2,2,0,1,2)$ & -6.827204 & -6.220018 & -6.632960 & 0.999612 \\
\hline $\operatorname{ARDL}(2,2,1,1,2)$ & -6.761869 & -6.107976 & -6.552683 & 0.999588 \\
\hline $\operatorname{ARDL}(2,2,0,2,2)$ & -6.760603 & -6.106710 & -6.551417 & 0.999588 \\
\hline $\operatorname{ARDL}(2,2,1,2,2)$ & -6.695288 & -5.994689 & -6.471160 & 0.999561 \\
\hline
\end{tabular}

Source: Author estimates from KPLC, Economic surveys, World Bank statistics and KenGen data.

Table 6: Residual and stability diagnostic test results

\begin{tabular}{|l|l|l|l|l|l|}
\hline Description & $\begin{array}{l}\text { LM serial } \\
\text { correlation }\end{array}$ & Normality & Heteroskedasticity & $\begin{array}{l}\text { CUSUM and } \\
\text { CUSUM of } \\
\text { squares }\end{array}$ & Conclusion \\
\hline $\begin{array}{l}\text { Intercept and } \\
\text { no trend } \\
\text { model }\end{array}$ & 0.4686 & 0.6192 & 0.3375 & $\begin{array}{l}\text { within the } \\
\text { confines of } \\
\text { the 5\% } \\
\text { significance }\end{array}$ & $\begin{array}{l}\text { Diagnostic } \\
\text { tests passed }\end{array}$ \\
\hline
\end{tabular}

Source: Author estimates from KPLC, Economic surveys, World Bank statistics and KenGen data.
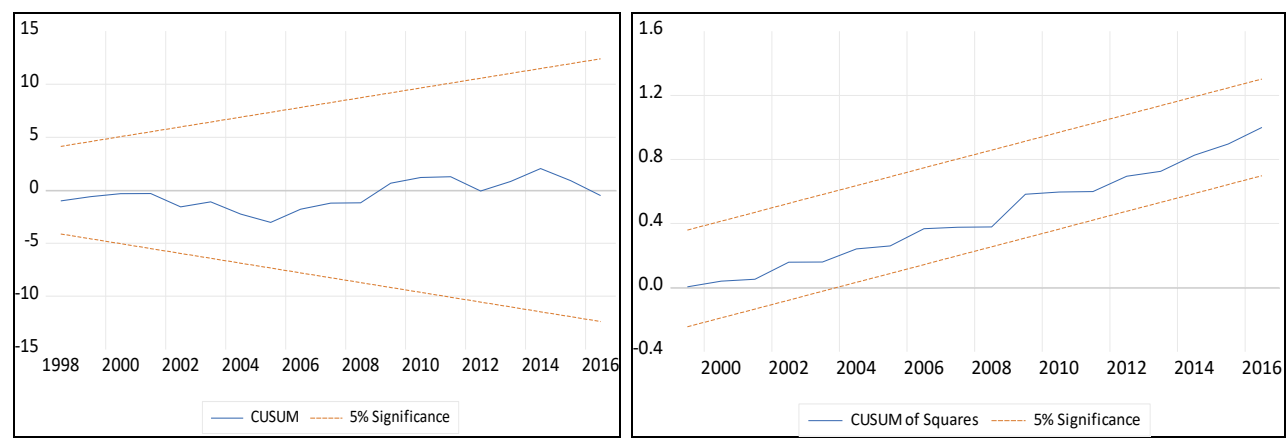

Figure 1: CUSUM and CUSUM of squares 


\subsection{Cointegration test}

Table 7:Bounds Test Cointegration results for commercial and industrial electricity demand ARDL model $(2,2,0,1,2)$

\begin{tabular}{|l|l|l|l|l|}
\hline Description & \multicolumn{2}{|l|}{ Critical Values } & F statistics & Conclusion \\
\hline \multirow{4}{*}{$\begin{array}{l}\text { Restricted } \\
\text { intercept no trend }\end{array}$} & $\mathrm{I}(0)$ & $\mathrm{I}(1)$ & 12.78 & $\begin{array}{l}\text { Long-run } \\
\text { relationship } \\
\text { exists }\end{array}$ \\
\cline { 2 - 3 } & $2.2(10 \%)$ & $3.09(10 \%)$ & & \\
\cline { 2 - 3 } & $2.56(5 \%)$ & $3.49(5 \%)$ & & \\
\cline { 2 - 3 } & $3.29(1 \%)$ & $4.37(1 \%)$ & & \\
\cline { 2 - 3 } & $3.03(10 \%)$ & $4.06(10 \%)$ & & \\
\cline { 2 - 3 } & $3.47(5 \%)$ & $4.57(5 \%)$ & & \\
\cline { 2 - 3 } & $4.4(1 \%)$ & $5.72(1 \%)$ & & \\
\hline
\end{tabular}

Source: Author estimates from KPLC, Economic surveys, World Bank statistics and KenGen data.

The bounds test cointegration test results are provided in Table 7 . The test found an existing long-run relationship between commercial and industrial electricity demand on one part and income, electricity price, industry efficiency, hydro inflows, connections and reforms on the other.

\subsection{Determinants of commercial and industrial demand for electricity in Kenya}

Table 8: ARDL estimates of elasticities of demand for commercial and industrial electricity in Kenya

\begin{tabular}{|l|l|}
\hline Variable & Coefficient \\
\hline Short-run estimates & \\
\hline C & -14.301 \\
Commercial and industrial & $(2.096)$ \\
\hline Electricity consumption(t-1) & $-0.750^{* * *}$ \\
\hline Energy Efficiency (t-1) & $(0.114)$ \\
\hline Output (t-1) & $-0.734^{* * * *}$ \\
\hline & $(0.134)$ \\
\hline Hydro inflows & $0.847^{* * * *}$ \\
\hline & $(0.128)$ \\
\hline Price of Electricity(t-1) & $0.011^{*}$ \\
\hline Change in Commercial and industrial & $(0.006)$ \\
\hline Electricity consumption(t-1) & $-0.022^{* *}$ \\
\hline & $(0.008)$ \\
\hline D(Energy Efficiency) & $0.614^{* * *}$ \\
\hline & $(0.135)$ \\
\hline Change in Energy Efficiency(t-1) & $-0.972^{* * *}$ \\
\hline Change in Output & $(0.039)$ \\
\hline Change in Output(t-1) & $0.572^{* * *}$ \\
\hline
\end{tabular}




\begin{tabular}{|l|l|} 
& -0.003 \\
Change in Price of Electricity & $(0.007)$ \\
\hline Reform & $-0.054^{* * *}$ \\
\hline ECT & 0.008 \\
\hline Long-run estimates & $-0.750^{* * *}$ \\
$(0.075)$
\end{tabular}

Source: Author's estimates from KPLC, KNBS, World Bank and KenGen data. Notes: *** indicates significance at $1 \%$ level; ** indicates significance at $5 \%$ level; * indicates significance at $10 \%$ level. The standard errors are in paranthesis.

The estimated short and long-run elasticities of demand are presented in Table 8. The estimated coefficients had the expected signs and were consistent with economic theory that stipulates demand to be a factor of price and income. The short-run elasticities were smaller than the long-run due to the time taken to make any adjustment to electricity consumption in the shortrun. The error correction term was significant and negative indicating convergence to the equilibrium.

In the short-run, an increase in income by $1 \%$ increased electricity consumption in the next period by $0.84 \%$. A $1 \%$ change in income increased electricity demand with $1.05 \%$. This can be attributed to the need for more energy to produce the extra units of outputs, of which in the short-run period, alternative inputs into the production process may be difficult for the firms to adopt. However, a $1 \%$ change in income in the previous period was likely to decrease electricity demand in the current period by $0.67 \%$. This could be as a result of consumers having a one-year period to make changes into their production processes.

In the long-run, commercial and industrial electricity demand was income elastic. This finding was consistent with Cebule and Herder (2010), Otsuka (2015) and Campbell (2018). A 1\% increase in income increased electricity consumed by commercial and industrial consumers by $1.13 \%$. Other studies that found electricity demand for commercial and industrial electricity consumers to be positively affected by the level of economic activity include Dilaver and Hunt (2010) in a study for Turkey, Ghaderi et al. (2006b) in a study for Iran and Sabir et al. (2013) in a study for Pakistan. 
Electricity demand was found to be price inelastic in the short and long-run. In the short-run a $1 \%$ increase in the price of electricity decreased electricity demand by $0.02 \%$ in the subsequent period. In the long-run, a $1 \%$ increase in the price of electricity decreased electricity demand by $0.03 \%$. The negative relationship between price and demand is consistent with demand theory for a normal good. Inelastic electricity demand with respect to price was also found by Campbell (2018) study for Jamaica, Otsuka (2015) study for Japan, Cebule and Herder (2010) study for the United States, Bjorner and Togeby (1999) study for Denmark, Dilaver and Hunt (2010) study for Turkey, Bianco et al. (2010) study for Romania and Sabir et al. (2013) in a study for Pakistan.

The study also found efficiency to be a significant determinants of demand in the short and long-run. In the short-run, $1 \%$ increase in energy efficiency reduced electricity demand in the next period by $0.73 \%$. A $1 \%$ change in energy efficiency decreased electricity demand by $0.97 \%$ in the current period but increased electricity demand by $0.57 \%$ in the subsequent period. In the long-run, a $1 \%$ increase in energy efficiency decreased electricity demand with $0.98 \%$. This finding is consistent with that of Cebule and Herder (2010).

Another significant determinant of commercial and industrial electricity demand was hydro inflows, as a proxy for supply side constraints. In the short-run, a $1 \%$ increase in hydro inflows increased electricity demand by $0.01 \%$. In the long-run a $1 \%$ increase in the hydro inflows increased demand for electricity by $0.015 \%$. None of the studies reviewed had included a variable for supply side constraints in their analysis. This finding is therefore a contribution to literature.

The reforms of 1998 were found to negatively affect electricity demand. This could be attributed to the coinciding of the reforms with the worst drought and economic recession declining the demand for electricity (Republic of Kenya, 2004). Previous period demand also negatively affected demand in the short-run. A $1 \%$ increase in previous period demand decreased demand in the current period with $0.75 \%$. This indicates that commercial and industrial consumers are likely to reduce their demand in the current period based on their previous period demand.

\subsection{Comparison of article forecast with the official forecasts}

Using the ARDL model forecasting was undertaken by amending the independent future variables.Table 9 shows the assumptions taken in forecasting in this article. Three scenarios were considered in line with the official government forecasts namely low, base and high scenarios. The base scenario is the most probable scenario and informs the investments implemented by government. A comparison of the economic growth rates 
assumptions with those used in the official forecasts indicates significant differences in Republic of Kenya (2013b) but minimal differences in Lahmeyer International GmbH (2016). Republic of Kenya (2013b) assumed growth rates of $6 \%$ for the low case, $10 \%$ for the base case and $12 \%$ for the high case. Lahmeyer International $\mathrm{GmbH}$ (2016) forecast assumed average GDP growth rate of $5.1 \%$ for the low case, $6.9 \%$ for the base case and $10 \%$ for the period beyond 2020 for the high case.

Table 9: Assumptions in forecasting commercial and industrial demand for electricity in Kenya to 2035

\begin{tabular}{|c|c|c|c|}
\hline Variable & $\begin{array}{l}\text { Optimistic scenario } \\
\text { assumption(high) }\end{array}$ & $\begin{array}{l}\text { Reference scenario } \\
\text { assumption (base) }\end{array}$ & $\begin{array}{l}\text { Pessimistic scenario } \\
\text { assumption (low) }\end{array}$ \\
\hline $\begin{array}{ll}\text { Price } & \text { of } \\
\text { electricity }\end{array}$ & $\begin{array}{l}\text { The electricity tariff was } \\
\text { assumed to reduce from } \\
15.56 \mathrm{KSh} / \mathrm{kWh} \text { in } 2016 \\
\text { to } 10.45 \mathrm{KSh} / \mathrm{kWh} \text { in } \\
2035 \text { as proposed by the } \\
\text { investment prospectus } \\
2013-2016 \text { (Republic of } \\
\text { Kenya, 2013a) }\end{array}$ & $\begin{array}{l}\text { The retail tariff was } \\
\text { projected to increase } \\
\text { from } 15.56 \mathrm{KSh} / \mathrm{kWh} \\
\text { in } 2016 \text { to } \\
16.33 \mathrm{KSh} / \mathrm{kWh} \text { in } \\
2035 \text {, the highest } \\
\text { recorded average tariff } \\
\text { in the study period } \\
1985 \text { to } 2016 \text { collected } \\
\text { from KPLC annual } \\
\text { reports. }\end{array}$ & $\begin{array}{l}\text { The retail tariff was } \\
\text { projected to increase } \\
\text { from } 15.56 \mathrm{KSh} / \mathrm{kWh} \text { in } \\
2016 \text { to } 24.64 \\
\mathrm{KSh} / \mathrm{KWh} \text { by the year } \\
2024 \text {. This is as } \\
\text { projected in Republic of } \\
\text { Kenya (2018c). The } \\
\text { retail tariff was assumed } \\
\text { to remain the same for } \\
\text { the remainder of the } \\
\text { forecast period }\end{array}$ \\
\hline $\begin{array}{l}\text { Hydro } \\
\text { inflows }\end{array}$ & $\begin{array}{l}\text { Assumed hydro inflows } \\
\text { to increase until they } \\
\text { reached } 2499 \text { Cumecs, } \\
\text { the highest inflows } \\
\text { recorded in the el-nino } \\
\text { period of } 2012 / 13 \text {. }\end{array}$ & $\begin{array}{l}\text { The inflows were } \\
\text { assumed to decline } \\
\text { from KenGen's } \\
\text { estimates of } 1053 \\
\text { Cumecs in } 2018 \text { to the } \\
\text { 35-year average } \\
\text { inflows of } 857 \text { Cumecs } \\
\text { by the year } 2035 \text {. }\end{array}$ & $\begin{array}{l}\text { Assumed the hydro } \\
\text { inflows will decrease } \\
\text { until they reach } 466 \\
\text { Cumecs, this is the least } \\
\text { inflows realised in the } \\
\text { drought period of } \\
2008 / 09 \text {. }\end{array}$ \\
\hline $\begin{array}{l}\text { Gross Value } \\
\text { added }\end{array}$ & $\begin{array}{l}\text { The growth rate } \\
\text { projections were; } 7.66 \% \\
\text { in } 2019 \text { and } 8.36 \% \text { in } \\
2020 \text { and the remainder } \\
\text { of the forecast period. } \\
\text { Assumed the vision } 2030 \\
\text { projections in the Kenya } \\
\text { Economic Report (Kenya } \\
\text { Institute for Public } \\
\text { Policy Research and } \\
\text { Analysis (KIPPRA), } \\
2017 \text { ) The projected } \\
\text { GDP growths were } \\
\text { adjusted to exclude the } \\
\text { contribution of taxes, } \\
\text { whose contribution was } \\
12 \% \text { in } 2017 \text { (KNBS, } \\
2018 \text { ). }\end{array}$ & $\begin{array}{l}\text { The projected growths } \\
\text { rates were; } 5.72 \% \text { in } \\
2019 \text { and } 5.9 \% \text { in } 2020 \\
\text { and for the rest of the } \\
\text { forecast period. } \\
\text { Assumed the baseline } \\
\text { projections in the } \\
\text { Kenya Economic } \\
\text { Report (KIPPRA, } \\
\text { 2017). An adjustment } \\
\text { similar to the high } \\
\text { scenario was } \\
\text { undertaken. }\end{array}$ & $\begin{array}{l}\text { The assumed growth } \\
\text { rates were; 5.37\% for } \\
\text { the forecasting period. } \\
\text { Assumed the low } \\
\text { projections in the Kenya } \\
\text { economic report } \\
\text { (KIPPRA, } \\
\text { Similar adjustment to } \\
\text { high and reference } \\
\text { scenario } \\
\text { undertaken. }\end{array}$ \\
\hline
\end{tabular}




\begin{tabular}{|l|l|l|l|}
\hline Variable & $\begin{array}{l}\text { Optimistic scenario } \\
\text { assumption(high) }\end{array}$ & $\begin{array}{l}\text { Reference scenario } \\
\text { assumption (base) }\end{array}$ & $\begin{array}{l}\text { Pessimistic scenario } \\
\text { assumption (low) }\end{array}$ \\
\hline $\begin{array}{l}\text { Energy } \\
\text { Efficiency }\end{array}$ & $\begin{array}{l}\text { Energy efficiency growth rates for the three scenarios were based on the energy } \\
\text { saving rate projections for industry, commercial and institutional sectors in the } \\
\text { generation and transmission masterplan. The rates were } 8 \% \text { for } 2018-2021, \\
4 \% \text { for 2022- 2024, 2\% for 2025-2027, 2.4\% for 2028-2033 and 1.4\% 2034- } \\
\end{array}$ \\
& 2035 (Lahmeyer International GmbH., 2016).
\end{tabular}

Source: Authors compilation from Republic of Kenya (2013a, 2018c), KNBS, KenGen,

KPLC, Lahmeyer International GmbH (2016) and (KIPPRA, 2017)

The results of the forecast are presented in Table 10. The two official forecasts are higher than this article's forecast. The forecast in Republic of Kenya (2013b) is the highest. It is over nine times the forecast in this article at $82,388 \mathrm{GWh}$ in 2033 in the reference scenario. The official forecast is, therefore, overstated. This can be attributed to the high economic growth assumptions as well non-considerations of other demand drivers.

Table 10: A comparison of the official forecast with the article forecast

\begin{tabular}{|c|c|c|c|c|c|c|c|c|c|}
\hline \multirow{3}{*}{ Year } & \multicolumn{3}{|c|}{ Low scenario } & \multicolumn{3}{|c|}{ Reference scenario } & \multicolumn{3}{|c|}{ High scenario } \\
\hline & Study & Lahmeyer & Republic of & Study & Lahmeyer & Republic of & Study & Lahmeyer & Republic of \\
\hline & Forecast & Inter & Kenya & Forecast & Inter. & Kenya & Forecast & Inter & Kenya \\
\hline 2019 & 5516 & 6520 & 8767 & 5603 & 6876 & 11644 & 5805 & 7104 & 13366 \\
\hline 2020 & 5465 & 6838 & 9556 & 5607 & 7324 & 13390 & 5969 & 7632 & 15772 \\
\hline 2021 & 5420 & 7160 & 10416 & 5612 & 7792 & 15399 & 6145 & 8088 & 18611 \\
\hline 2022 & 5590 & 7490 & 11353 & 5836 & 8288 & 17709 & 6575 & 8575 & 21960 \\
\hline 2023 & 5747 & 7833 & 12375 & 6051 & 8808 & 20365 & 7016 & 9093 & 25913 \\
\hline 2024 & 5899 & 8193 & 13489 & 6266 & 9355 & 23420 & 7477 & 9644 & 30578 \\
\hline 2025 & 6165 & 8571 & 14703 & 6612 & 9932 & 26933 & 8122 & 10234 & 36082 \\
\hline 2026 & 6440 & 8969 & 16026 & 6966 & 10539 & 30973 & 8806 & 10863 & 42576 \\
\hline 2027 & 6725 & 9387 & 17468 & 7332 & 11180 & 35619 & 9540 & 11534 & 50240 \\
\hline 2028 & 6995 & 9827 & 19040 & 7685 & 11876 & 40962 & 10291 & 12251 & 59283 \\
\hline 2029 & 7277 & 10290 & 20754 & 8056 & 12598 & 47106 & 11103 & 13017 & 69954 \\
\hline 2030 & 7571 & 10775 & 22622 & 8445 & 13368 & 54172 & 11980 & 13835 & 82546 \\
\hline 2031 & 7876 & 11287 & 24658 & 8853 & 14189 & 62297 & 12926 & 14710 & 97404 \\
\hline 2032 & 8193 & 11825 & 26877 & 9281 & 15067 & 71642 & 13947 & 15643 & 114937 \\
\hline 2033 & 8522 & 12391 & 29296 & 9730 & 16001 & 82388 & 15049 & 16641 & 135626 \\
\hline 2034 & 8951 & 12988 & & 10302 & 16999 & & 16399 & 17708 & \\
\hline 2035 & 9393 & 13604 & & 10899 & 18041 & & 17837 & 18849 & \\
\hline $\begin{array}{l}\text { Average growth } \\
\text { rate }(\%)\end{array}$ & $3.4 \%$ & $4.7 \%$ & $9.0 \%$ & $4.3 \%$ & $6.2 \%$ & $15 \%$ & $7.3 \%$ & $6.3 \%$ & $18 \%$ \\
\hline
\end{tabular}

Source: Author's compilation from own forecast, Lahmeyer International GmbH (2016) forecast and Republic of Kenya (2013b) forecast.

\section{Conclusions and Policy recommendations}

The study sought to estimate drivers and forecast demand for commercial and industrial electricity consumers. The results showed the key drivers were efficiency, income, hydro inflows(supply side constraints) and 
price of electricity. Commercial and industrial electricity demand was found to be income elastic but price inelastic. The demand is estimated to rise to $10,899 \mathrm{GWh}$ by 2035 in the reference scenario, representing an average growth rate of $4.3 \%$. The comparison of the forecast with the official goverment forecast indicates the goverment forecast may be overstated.

Price of electricity was found to be a significant consideration for commercial and industrial consumers. The government and the regulatory agency should be careful of this causal effect on the demand when setting electricity tariffs. Innovative policy measures such as special tariffs for industrial parks, time of use tariffs and tax rebates should be considered.

The government should also address supply side issues to ensure stable energy supply.The proposed measures include diversification of energy supply sources to avoid dependency on hydro generated energy that has resulted in load shedding programs in the past during drought. Electricity access and grid strengthening programs should also be implemented to reduce suppressed and unmet demand associated with lack of power supply and power blackouts respectively.

The Ministry of Energy initiated several generation capacity expansion projects that would see the installed capacity grow to $6,700 \mathrm{MW}$ by 2016 (Republic of Kenya, 2013a). This was later revised to 5,221MW by 2022 (Republic of Kenya, 2018b). This expansion was largely informed by anticipated growth in demand from commercial and industrial consumers. From the projections in this article the anticipated growth in electricity demand was overstated. The Ministry of Energy should review the planned generation projects to avoid a situation of excess supply and stranded capacity that would in turn increase electricity costs.

\section{References:}

1. Belloumi, M. (2014) The relationship between trade, FDI and economic growth in Tunisia: An application of the autoregressive distributed lag model. Economic systems 38(2):269-287.

2. Bernstein, R. and Madlener, R. (2010). Short and Long-Run Electricity Demand Elasticities at the Subsectoral level: A Cointegration Analysis for German Manufacturing Industries. Institute for future Energy Consumer Needs and Behaviour, working paper No. 19/2010, Aachen.

3. Bhattacharyya, S. C. (2011). Energy Economics: Concepts, issue, markets and governance. London, UK: Springer-Verlag.

4. Bhattacharyya, S. C., and Timilsina, G. R. (2009). Energy demand models for policy formulation: A comparative study of energy demand models. The World Bank policy research working paper No. 4866. 
5. Bianco, V., Manca, O. Nardini, S. and Minea, A. A. (2010). Analysis and forecasting of non- residential electricity consumption in Romania. Applied Energy 87:3584-3590.

6. Bjørner, T. and Togeby, M. (1999). Industrial companies' demand for energy based on a micro panel database - Effects of $\mathrm{CO} 2$ taxation and agreements on energy savings. In energy efficiency and CO2 reduction. Institute of Local Government Studies, Denmark. Downloaded from http:// www.citeseerx.ist.psu.edu on 16/11/12.

7. Burke, P. J., \& Abayasekara, A. (2018). The price elasticity of electricity demand in the United States: A three-dimensional analysis. The Energy Journal 39(2):123-145. Downloaded from https://www.iaee.org on the 13/04/2020.

8. Campbell, A. (2018). Price and income elasticities of electricity demand: Evidence from Jamaica. Energy Economics 69:19-32. Downloaded from https://www.sciencedirect.com/science/article on 13/04/2020.

9. Cebula, R. J. and Herder, N. (2010). An empirical analysis of determinants of commercial and industrial electricity consumption. Business and Economics Journal 1(1):1-7.

10. Chaudhry, A. A. (2010). A panel data analysis of electricity demand in Pakistan. The Lahore Journal of Economics 15:75-106.

11. Dilaver, Z. and Hunt, L. C. (2010). Industrial electricity demand for Turkey: A structural time series analysis. Surrey energy economics discussion paper series (SEEDS) 129, Department of Economics, University of Surrey, Guildford.

12. Electricity Regulatory Board, (2005). Retail electricity tariffs review policy. Electricity regulatory board, Nairobi.

13. Francisco R. C. (1988). Demand for electricity in the Philippines: implications for alternative electricity pricing policies. The Philippine institute for development studies. Kolortech Co. Manila.

14. Ghaderi, F. S., Azadeh, A. M., and Mohammadzadeh, S. (2006a). Modelling and forecasting the electricity demand for major economic sectors of Iran. Information Technology Journal 5(2):260-266.

15. Ghaderi, S. F., Azadeh, M. A., and Mohammadzadeh, S. (2006b). Electricity demand function for the industries of Iran. Information Technology Journal 5(3):401-404.

16. Khayyat, N. T. (2015). Energy demand in industry: what factors are important? Dordrecht,Netherlands:Springer Science+Business Media.

17. Kenya Institute for Public Policy Research and Analysis. (2017). Kenya economic report 2017. KIPPRA, Nairobi.

18. Kenya National Bureau of Statistics. (2019). Economic survey 2019. Government printer, Nairobi. 
19. Kenya Power and Lighting Company. (2019). Draft Annual report and financial statements.Financial year ended $30^{\text {th }}$ June 2019. Personal communication.

20. Lahmeyer, International. GmbH. (2016). Development of a power generation and transmission master plan, Kenya: long term plan 2015-2035. Lahmeyer International GmbH, Frankfurt.

21. Magazzino, C. (2014). Electricity demand, GDP and employment: evidence from Italy. Frontiers in Energy 8(1):31-40. Downloaded from https://academia.edu.documents on 13/04/2020.

22. Magazzino, C. (2017). Stationarity of electricity series in MENA countries. The Electricity Journal 30(10):16-22. Downloaded from https://academia.edu.documents on 13/04/2020.

23. Pesaran, H. M., Shin, Y. and Smith, R. J. (2001). Bound testing approaches to the analysis of long-run relationships. Journal of Applied Econometrics 16(3):289-326.

24. Republic of Kenya, (2004). Sessional Paper No 4 of 2004 on Energy. Ministry of Energy, Nairobi.

25. Republic of Kenya. (2007). Kenya Vision 2030: A globally Competitive and Prosperous Kenya. Government printer, Nairobi.

26. Republic of Kenya. (2013a). 5000MW+ by 2016, power to transform Kenya.Investment Prospectus 2013-2016.Ministry of Energy and Petroleum, Nairobi.

27. Republic of Kenya. (2013b). Updated Least Cost Power Development Plan 2013-2033. Ministry of Energy and Petroleum, Nairobi.

28. Republic of Kenya. (2018a). The Kenya National Electrification Strategy. Ministry of Energy, Nairobi.

29. Republic of Kenya. (2018b). Kenya Electricity Sector Investment Prospectus 2018 - 2022. Ministry of Energy, Nairobi.

30. Republic of Kenya. (2018c). Updated Least Cost Power Development Plan 2017-2037. Personal communication.

31. Sabir, M., Ahmad, N. and Bashir, M. K. (2013). Demand function of electricity in industrial sector of Pakistan. World Applied Sciences Journal 21(4):641-645.

32. Otsuka, A. (2015). Demand for industrial and commercial electricity: evidence from Japan. Journal of Economic Structures 4(9):1-11. Downloaded from https://link.springer.com on 13/04/2020. 